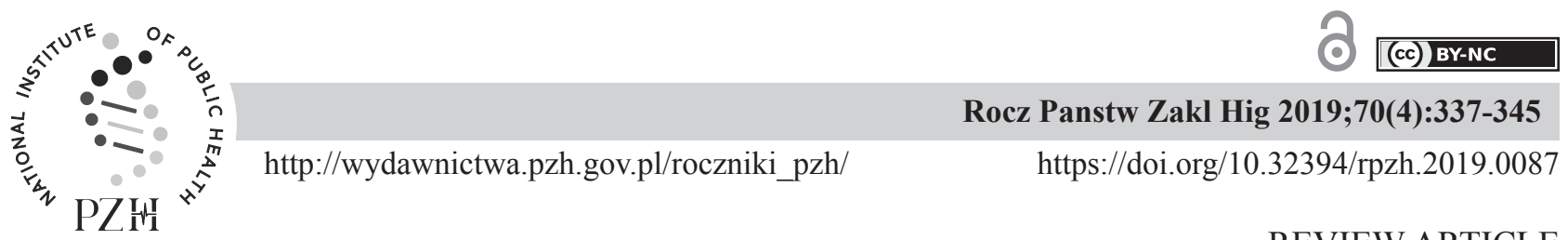

REVIEW ARTICLE

\title{
IMPORTANCE OF DIET IN REDUCING CANCER INCIDENCE IN POLAND: A REVIEW
}

\author{
Michat Zych', Krzysztof Stec ${ }^{1}$, Agnieszka Bąblewska², Karol Pilis ${ }^{1}$
}

${ }^{1}$ Institute of Physical Education, Tourism and Physiotherapy, Jan Dlugosz University in Czestochowa, Poland ${ }^{2}$ Department of Biochemistry, Biotechnology and Ecotoxicology, Jan Dlugosz University in Czestochowa, Poland

\begin{abstract}
Cancer is one of the leading causes of death in most countries in the world. In Poland, after cardiovascular disease, cancer is the leading cause of death, and the number of malignant tumors has more than doubled in the last three decades. Increased cancer mortality in the immediate future is expected to be mainly associated with lung cancer caused by smoking (both sexes), colorectal cancer (both sexes), breast cancer in women, and prostate cancer in men. It is estimated that 20 to $30 \%$ of all malignant tumors are diet-dependent, in which cases the cancer-inducing factors are the nutritional components of the food and the 'hygiene' of eating. Research by the Institute of Food and Nutrition in Warsaw indicates that an important factor in the prevention of cancer is also the individual's state of awareness concerning diet. It is emphasized that running nutritional education programs, especially for children and adolescents, may help to limit the occurrence of diet-dependent cancers in Poland over the next few decades. The aim of this review is to assist the promulgation of knowledge about the importance of a high-quality diet in the prevention of cancer. The need for such knowledge is indicated by the upward trend in the incidence of these types of disease in Poland.
\end{abstract}

Key words: nutrition, diet, cancer, prevention

\section{STRESZCZENIE}

Choroby nowotworowe stanowią jedną z głównych przyczyn zgonów w różnych krajach świata. W Polsce nowotwory obok chorób układu krążenia są jedną z przyczyn największej ilości zgonów, a liczba zachorowań na złośliwe rodzaje tych schorzeń wzrosła ponad dwukrotnie w ciągu ostatnich trzech dekad. Umieralność z powodu prognozowania dotyczące dalszego wzrostu ilości tych zachorowań, związane są głównie z paleniem tytoniu i dotyczą nowotworów jelita grubego u obu płci oraz nowotworów płuca oraz piersi u kobiet, jak również prostaty w populacji mężczyzn. Uznaje się, że około 20 - 30\% wszystkich nowotworów złośliwych stanowią nowotwory dietozależne, w których czynnikiem indukującym raka są składniki żywieniowe oraz higiena odżywiania. Badania Instytutu Żywności i Żywienia w Warszawie wskazują, że ważnym czynnikiem profilaktyki zachorowalność na nowotwory złośliwe jest również stan świadomości związanej ze stosowaną dietą. Podkreśla się również, że prowadzenie edukacji żywieniowej już u dzieci i młodzieży może ograniczać występowanie nowotworów dietozależnych w Polsce. Celem niniejszego artykułu jest popularyzacja wiedzy na temat jakości diety stosowanej w profilaktyce chorób nowotworowych, $\mathrm{z}$ uwagi na niekorzystną tendencję wzrostową zachorowalności na te rodzaje schorzeń w Polsce.

Słowa kluczowe: pożywienie, dieta, choroby nowotworowe, zapobieganie

\section{INTRODUCTION}

Cancer is one of the leading causes of death in developed and developing countries around the world. The term cancer is understood to mean an abnormal, excessive growth of tissue originating from normal cells of the body that have undergone cancerous transformation. Over time, cancer cells in the case of malignant tumors are transferred by the lymphatic or blood circulatory systems to other organs of the body, creating secondary foci (metastases). The primary causes of cancerous transformation are mutations in proto-oncogenes, anti-oncogenes and mutator genes regulating the cell cycle, and DNA repair systems. Both genetic factors (affecting about $10 \%$ of the population) and environmental factors (affecting about $80 \%$ of the population) are involved in the development of tumors. The environmental factors include ionizing

Corresponding author: Krzysztof Stec, Uniwersytet Humanistyczno-Przyrodniczy im. Jana Długosza, Instytut Wychowania Fizycznego, Turystyki i Fizjoterapii, ul. Armii Krajowej 13/15, 42-200 Częstochowa, tel.: +48 537 507 558, e-mail: krzysztof.z.stec@gmail.com 
radiation, excessive exposure to the sun, factory fumes, some metals (asbestos, lead, nickel, chromium), dioxins (from grilled food, cigarette smoke, garbage incineration smoke, car fumes), smoking tobacco, medicines, viruses and bacteria, alcohol and certain types of diet (DeVita et al. 2011).

According to reports from the GLOBOCAN project, in 2012 there were about 14.1 million new cases of cancer and 8.2 million deaths related to cancer in the whole world. It is presumed that in the near future cancerous diseases will be the main cause of deaths for both men and women before the age of 65 (Torre et al. 2015). In Poland, cancer is the second highest cause of death, and the number of malignant tumors has more than doubled in the last three decades. Mortality from malignant tumors in Poland is higher than the average for other European Union countries. The most common cases of malignant tumors in men are found in the lungs (about $20 \%$ of cases), the prostate $(13 \%)$, the colon and rectum (12\%), the bladder (7\%), and then the stomach, kidneys, larynx, and circulatory systems (leukemia and lymphoma). Among women the incidence is breast cancer (over $20 \%$ of cases), large intestine (10\%), lungs (9\%), uterine body $(7 \%)$, ovary $(5 \%)$, and then cervix, kidneys, stomach and thyroid. The number of deaths from malignant tumors in Poland in the last five decades has increased by almost 2.4 times (Didkowska et al., 2017, Europejski Raport Zdrowia, 2013).

Research conducted at the Institute of Food and Nutrition in Poland indicates that the state of health of Poles, including the incidence of malignant tumors, could have been affected by changes in the quality of nutrition. After the political transformation of 1989 , dietary habits in the country changed for better and for worse. Among the favorable trends occurring in the period since then were, firstly, an increased consumption of vegetables and fruits, resulting in a higher content of vitamin $\mathrm{C}$ in the diet, and, secondly, a reduced consumption of red meat, resulting in an associated reduction in the consumption of animal fats. In addition, there was a reduction in salt intake and an increase in the content of vitamin D. These dietary changes were accompanied by a reduction in the number of cigarettes smoked. However, despite there having been some favorable changes in nutrition, certain negative trends have also become apparent, such as an increase in alcohol consumption, a decrease in dairy product consumption, resulting in a reduced supply of calcium in the diet, a decrease in the consumption of cereal products, resulting in a reduction in foliate and fiber consumption, and an increase in the fat content of the diet (Jarosz, 2017). The special relationship between diet and cancer is shown by the incidence of colon and rectal tumors. In the last few decades, there has been an increase in both morbidity and deaths among
Poles from these cancers to the extent of a four-fold increase in the incidence of the cancers among men and a three-fold increase among women. The research of Didkowska et al. (2009), regarding the prognosis of morbidity and mortality of Poles due to cancer, indicates that a significant increase is likely to occur in the coming years, especially due to cancer associated with smoking. These studies suggest a future increase in the incidence of lung and colorectal cancer in both sexes, breast cancer in the female, and prostate cancer in the male population.

The aim of this article is to assist the promulgation of knowledge about the role of diet in the prevention of cancer. This is considered essential because of the unfavorable upward trend in the incidence of cancer in Poland.

\section{DISCUSSION}

\section{DIETARY MISTAKES STIMULATING THE DEVELOPMENT OF CANCER IN POLAND}

Some of the main reasons for the increased incidence of cancer are dietary errors. These include excessive consumption of industrially processed food products. Such products contain significant amounts of preservatives that, in stimulating the production of free radicals, damage the genetic material of cells and thus lead to cancer transformation (Valko et al. 2006). Mutations in the genome are very often also caused by toxic factors in the products themselves; such products would include those with an excessive content of nitrogen compounds (N-nitro compounds, nitrates and nitrites) from chemical fertilizers. This particularly dangerous phenomenon concerns the reduction of intestinal nitrates to nitrites and oxides under the influence of intestinal bacteria, which may result in carcinogenic nitrosamines (Hamra et al, 2015). Improper processing of food products, as in processes of smoking, grilling or frying of relatively long duration, can be a source of carcinogenic heterocyclic amines and polycyclic aromatic hydrocarbons that easily penetrate into food (Moorthy et al., 2015). One of the great dietary errors is the consumption of stale foods. Such foods may contain shreds of mushrooms from the Aspergillus family that are the source of carcinogenic aflatoxins. Consumption of some products in excess may cause the development of many diseases, including cancers. One example of such products is alcohol, which in excess can destroy mucous membranes of the respiratory and digestive tracts, thus enabling the toxic effects of carcinogens to manifest themselves in the associated tissues (Varela-Rey et al, 2013). Excessive fat intake affects the proliferation of cells that have undergone cellular transformation, which speeds up the development of cancer (Park et al, 2018). The increased amount of 
animal protein consumed, e.g. in red meat, which is subjected to thermal treatment, also contributes to the formation of carcinogenic changes and excessive amounts of free radicals (Yen et al, 2018). Consumption of excess table salt affects the mucous membrane of the stomach and intestines, which increases its permeability also for harmful substances (D'Elia et al, 2014). The study also suggests that total amount of fiber in the diet is a strong protecting factor against colorectal cancer. Moreover, soluble and insoluble fiber consumption is in inverse relationship to the incidence of colorectal and colon cancer (Song et al, 2015).

\section{NUTRIENTS REDUCING THE INCIDENCE OF CANCER}

Natural factors that strengthen the body's immunity are physical activity, optimal sleep, and a proper diet. Such a diet should contain the right amount of highvalue proteins, polyunsaturated fatty acids, vitamins with antioxidant activity, flavonoids, minerals and probiotics (Kaledkiewicz and Lange, 2013). Among the food ingredients that reduce the risk of cancer are those compounds with a strong antioxidant effect. However, it should be noted that too high a concentration of antioxidants in the diet may result in their role's being reversed, with the result that the protective substances become oxidants, thus contributing to serious disease symptoms (Bast and Haenen, 2002). Antioxidants behaving in this way include vitamins with properties that inactivate free radicals, e.g. vitamins C, E, D, $\mathrm{B}_{12}$ and folic acid. The strongest antioxidant activity among these vitamins is obtained from ascorbic acid (vitamin C), which increases cellular immunity and thus reduces the incidence of cancer. It can also effectively inhibit the formation of carcinogens such as nitrosamines contained in nitrite-conserved foods. It inhibits nucleic acid oxidation, thus preventing DNA damage and providing genome stability (Kaput and Rodriguez, 2004). Vitamin E, as a component of phospholipids that build cell membranes and blood plasma lipoproteins, protects against the peroxidation of polyunsaturated fatty acids and interacts with vitamin $\mathrm{C}$ in inhibiting the formation of nitrosamines. It is a powerful antioxidant and, like vitamin $C$, inhibits the oxidation of nucleobases, thereby preventing DNA damage leading to, for example, the formation of colon cancer (Kaput and Rodriguez, 2004). An important role in inhibiting cancer cell proliferation, by regulating growth and differentiation, is played by vitamin $\mathrm{D}$ (Jacobs et al, 2005). Research by Peters et al. (2001) confirmed a reduction in the risk of colorectal cancer by $26 \%$ when there was an increase in vitamin $\mathrm{D}$ concentration in serum of $10 \mathrm{ng} / \mathrm{ml}$. Vitamin D is also a stimulator of calcium binding protein biosynthesis, thanks to which a larger amount of this element is absorbed in the intestine. Vitamin $B_{12}$ is involved in cell metabolic processes and protects against DNA strand damage (Xiao et al, 2014).

An important group of factors that reduce the incidence of cancer is the carotenoids, which include $\beta$-carotene, lycopene, lutein, canthaxanthin and zeaxanthin. It is a group of organic chemical compounds (unsaturated hydrocarbons) that occur in chloroplasts and chromatophores of plant cells, e.g. vegetables and fruits, giving them the colors yellow, red, and orange. Carotenoids are powerful antioxidants. They stimulate the immune system of the body, inhibit cell proliferation, capture free radicals, inhibit mutagenesis in bacterial cells, inhibit chemically induced neoplastic processes, protect cells from UV radiation, and protect cells against neoplastic transformation. In addition, they dissolve in fats, protecting unsaturated fatty acids against oxidation. The strongest antioxidant ability is demonstrated by lycopene. Its activity consists in preventing the oxidation of LDL lipoproteins. Lycopene also has antimutagenic and anti-cancer activity, especially with regard to lung cancer (Nguyen and Schwatz, 1999, Pouchieu et al, 2014). Another important group of plant compounds showing antioxidant activity is the polyphenols, which include flavonoids, isoflavones, catechin phytoestrogens, stilbene and lignin. Anticancer activity of these compounds in food products consists in removing heavy metals, enhancing the action of other antioxidants (vitamins $\mathrm{A}$ and $\mathrm{E}$ ), inhibiting and strengthening the activity of some enzymes responsible for immunological functions, and inhibiting carcinogenesis and cell proliferation. Examples of polyphenols that effectively counteract cancer are anthocyanins that stimulate phase II antioxidants and the expression of detoxification genes such as reductase, peroxidase and glutathione S-transferase (Singletary et al, 2007). In addition, anthocyanins, like other polyphenols, influence regulatory proteins, thus controlling various stages of the cell cycle, which effectively inhibits the proliferation of cancer cells (Zhang et al, 2005). According to Feng et al. (2007), the extract obtained from black cranberries and grapes containing anthocyanins and anthocyanidins activates the process of programmed cell death (apoptosis). The phenolic acids constituting a group of plant chemopreventive compounds are also significant. These include coffee, chlorogenic, ferulic, elagic and gallic acids. The phenolic acids have the ability to block the carcinogens formed as a result of metabolic transformations of some carcinogenic substances such as 4 - nitroquinoline - 1 oxides. The health-promoting properties of phenolic acids are also associated with their antioxidant properties (Andreasen et al, 2001). Another group of glycoside 
compounds of vegetable origin in consumed foods that act as cytotoxic to cancer cells is the saponins. These compounds stimulate the body's immunity and inhibit the proliferation of cancer cells (Sisto et al, 2012). In plant foods, phytosterols have an important role to play in reducing the incidence of some cancers. These compounds inhibit cell proliferation, inhibit metastasis, induce apoptosis and remove free radicals (Jarosz and Sajor 2010, Pieszka and Pietras 2010). Regularly taken as part of a diet they are effective in lowering cholesterol levels, and thus reducing the risk of atherosclerosis and heart attack, by acting against teratogen and being anti-inflammatory.

Among the phytochemicals that protect against cancer are sulforaphane, isothiocyanates, and glucosinolates, which also help to prevent heart disease. They affect all stages of the neoplastic process, the strongest effect being observed at the initiation stage. This was confirmed by Chung et al. (2000), who showed that dietary supplementation with sulforaphane and phenethyl isothiocyanate (PEITC) results in reduction of neoplastic changes during the initiation phase and promotion of carcinogenesis. The protective properties of sulforaphane have been observed in all stages of carcinogenesis. This compound has been shown to block the binding site of carcinogens to the DNA molecule and prevent the expansion of neoplastic cells by interfering with their cellular processes involving proliferation, differentiation and apoptosis (Hakama, 1998).

Two essential elements in the diet that reduce the incidence of cancer are calcium and selenium. An appropriate calcium content in the body effectively inhibits the proliferation of cancer cells (Platz and Giovannucci, 1999). According to Fenech et al. (2005), high levels of calcium protect the genome from damage, due to calcium's ability to inhibit chromosomal cracking [2]. Selenium is a component of many enzymes with antioxidant activity. The anticancer activity of this element consists in blocking the synthesis of DNA in neoplastic cells. In addition, it inhibits the oxidation of lipids and removes free radicals. According to Fenech et al. (2005), a deficiency of it may cause hypomethylation of DNA, which may lead to inappropriate gene expression and to genetic instability.

An important nutrient that indirectly protects against cancer is fiber, which contains such substances as hemicelluloses, pectin, cellulose and lignin. The protective mechanism of fiber activity manifests itself in a number of ways. First of all, fiber increases bulk stool and dilutes fecal carcinogens, as well as shortening fecal transit time in the colon. In these ways the amount of contact carcinogens have with the colon epithelium is reduced (Bingham, 1990, Schatzkin 2000). Moreover, fiber binds to the bile acid by which it optimizes the $\mathrm{pH}$ inside the colon. Excess, non-binding bile acid, can be a carcinogenic factor (Wakai et al. 2007, Bermudez-Soto et al. 2007). It is well known that the fiber is fermented inside the gut to the short-chain fatty acids. Some of them inhibit carcinogenesis (Goncalves and Marteal, 2013). It was also observed that a bigger dose of fiber can reduce hyperinsulinemia (Hawk et al., 2002). In other studies Trepel (2004), Willett (2000) and Augenlicht (1999) demonstrated the contribution of fiber to maintaining the balance between proliferation, differentiation and apoptosis of colon epithelial cells. The presence in the gastrointestinal tract of bacteria of the genus Lactobacillus, Escherichia and Bifidibacterium inhibits the growth and development of carcinogenic pathogens. The sources of beneficial bacterial strains are probiotics. Lactic bacteria have the ability to bind and degrade potential carcinogens, as well as to induce the activity of enzymes involved in their metabolizing (Fotiadis et al., 2008).

The presence of polyunsaturated fatty acids in the diet reduces the risk of cancer. These acids are part of phospholipid cell membranes, and their anti-cancer character results from their participation in the growth and differentiation of cells and their influence on the course of inflammatory processes and the body's immune response.

\section{THE IMPACT OF DIET ON REDUCING THE RISK OF CANCER INCIDENCE IN POLAND}

One of the most important components of lifestyle is diet, which is an important factor in the formation of malignant tumors. It is estimated that 20 to $30 \%$ of all malignant tumors are diet-dependent cancers, in which nutritional factors have played an important role. Among these are cancer of the breast, the large intestine, the esophagus, the stomach, and the pancreas (Pudlo et al., 2015). An ideal nutritional model that may be used in the prevention of cancer has been sought. According to Tantamango-Bartley et al. (2013), the sort of vegetarian diet that reduces the risk of colon, breast and prostate cancer deserves special attention. This diet contains a variety of nutrients with anti-carcinogenic properties, eliminates the eating of red meat, and is conducive to the maintenance of a proper body weight. The advantages and limitations of using a vegetarian diet in health prophylaxis are also described extensively in the Polish literature (Mitek et al. 2013, Pilis et al. 2014). Among the diets recommended in the prevention of cancer is the socalled Mediterranean diet, containing a large amount of polyunsaturated fatty acids, oleic acid and polyphenols (Turati et al. 2018, Robles-Almazan et al. 2018). 
The risk of malignant tumors associated with the digestive system, e.g. oral cancer, and cancers of the larynx, esophagus, stomach, pancreas, colon, etc., can be reduced by certain nutrients. Among them are such compounds as vitamin $\mathrm{C}$, lycopene, $\beta$-carotene, caffeic acid, acid chlorogenic, carotenoids, flavonoids, terpenes, limonoids, coumarin, antioxidants glutathione, phytosterols, folates, which are present in plant products. In the case of colorectal cancer, important are both calcium as a compound and lactic acid bacteria, both of which are found in dairy products (Ciborowska and Rudnicka 2012, Jarosz and Sajor 2013).

The World Cancer Research Fund and the American Institute for Cancer Research (Report, 2007) presented recommendations in the report designed to prevent the development of cancer. These recommendations are concerned with lifestyle, including care for physical condition, avoiding stimulants, and using the right diet. Of the ten most important recommendations more than half are concerned with proper nutrition. These recommendations include avoiding the consumption of sweetened beverages and high-energy food, especially highly processed food with a high content of fat and sugar. An important aspect of a healthy lifestyle is the consumption of the right amount of food tailored to the needs of each body in five portions each day, with appropriate proportions of vegetarian foods such as fruits, vegetables, whole grain cereals and seeds of legumes. It is important that normal body weight should be maintained, avoiding being overweight as well as being obese. It is particularly important to limit the consumption of red meat in the diet, especially when it has been subjected to smoking or salting, or when it contains preservatives. Recommendations to prevent the development of cancer also include reducing the consumption of alcohol and table salt, and the avoidance of spoiled food and dietary supplements.

\section{NUTRITIONAL PATTERN IN THE MOST COMMON CANCER DISEASES IN POLAND}

The highest incidence of malignant tumors in Poland is found in the categories of lung, colorectal, breast and prostate cancer.

Lung cancer is the cause of the highest number of deaths among oncological patients in highly developed countries. According to the latest data published by the International Agency for Research on Cancer (IARC), in 2012 there were 1.8 million cases of lung cancer in the world, which constitutes $13 \%$ of all cancers (Report 2015). In Poland, lung cancer is the most common malignancy both in terms of the number of cases and in terms of the number of deaths. In men, it accounts for about $21 \%$ of cases and in women $9 \%$. Lung cancer is generated by such factors as occupational exposure to asbestos, certain metals (lead, cadmium, arsenic, nickel), silica, and ionizing radiation. However, the most common cause of this disease is active smoking. In EU countries every fifth case of lung cancer is a so-called tobacco-dependent cancer. Gender also affects the risk of lung cancer, with the incidence of cases among men being three times higher than among women. The vast majority of cases of malignant lung cancer occur after the age of 50 (Szlitkus, 2018). The lung is one of the organs in which a tumor can develop for a very long time without there being any obvious symptoms. It is because of the lack of early symptoms that detection tends to be delayed. Furthermore, although lung cancer is one of the most common cancers, no screening for it is undertaken. Up to this point, only retrospective analysis of the causes and consequences of the disease by means of epidemiological studies has been possible.

Meta-analysis conducted by Koutsokera et al. (2013) confirmed the positive effect of eating fruit and vegetables in the fight against lung cancer. A beneficial effect was also noted with regard to the presence of black tea, fish, and cheese in the diet. Among food products that contribute to the development of lung cancer, the authors cite red meat. Similar conclusions were presented by Hosseini et al. (2014), who conducted a study on a group of 242 patients with lung cancer and a 484-person control group. The results indicated that vegetables, fruits, and sunflower oil may be protective factors against the occurrence of lung cancer, while food products that increase the risk of this cancer are non-wholegrain bread, white rice, beef, liver, and dairy products. Similar results were found in Poland by Hawrysz et al. (2015). They showed that people with lung cancer, compared to those without that disease, consumed significantly less often $(p=0.008)$ products such as vegetables, wholegrain bread, milk, sour milk drinks (yoghurt, kefir, etc.) and fish dishes. People with cancer more often $(p=0.02)$ consumed canned foods, such as meat, fish, vegetables and fruit, as well as powdered soups and pre-cooked soups.

Colorectal cancer is the third most common cancer in the world in men $(660,000$ cases, $10 \%)$ and the second in women (570,000 cases, $9 \%$ ). Almost $60 \%$ of cases occur in economically developed countries. In Poland, the incidence of colorectal cancer in 2013 was approximately 17,000, and since 1980 there has been more than a four-fold increase in the number of these cases. Most cases occur after the age of 50 (94\%), while in men they are about one and a half to two times more frequent than in women (Zyski et al., 2014). In most cases, colon or rectal cancer is formed on the basis of benign adenomas (polyps). As a result of genetic mutations occurring in individual cells, the adenoma is transformed into cancer. In the case of colorectal cancer, a relationship between morbidity and diet is 
indicated. According to many researchers, the risk of developing cancer of the large intestine increases with the excessive consumption of red meat, carbohydrates and animal fats combined with too low a supply of dietary fiber. The above thesis is confirmed by the meta-study of Gonzalez and Riboli (2010), which was based on a total of 519,978 participants. These authors showed the positive effect of dietary fiber on reducing the risk of developing colorectal cancer, and also the anticancer effects of consuming fish, calcium, vegetables and fruit. Among the nutrients mentioned as effectively reducing the risk of developing colorectal cancer were probiotics and prebiotics, folic acid, methionine, vitamin $\mathrm{D}$, selenium, vitamin $\mathrm{E}$, anthocyanins, procyanidins, phytoestrogens, isothiocyanates, curcumin and resveratrol (Trepel 2004, Kunnumakkara et al. 2009, Barone et al. 2008, Talalay et al. 2003).

Prostate cancer is one of the most commonly diagnosed malignant tumors among men. The incidence of prostate cancer is increasing and becoming an increasingly serious medical problem in the world. The main risk factors for developing prostate cancer are old age, genetic determinants, a diet high in saturated fats, and heavy metal poisoning. The disease usually develops asymptomatically, and the emerging symptoms indicate its advanced stage (Twardak et al. 2015). In Poland, prostate cancer is ranked second in terms of cancer incidence in men. The number of new cases is constantly increasing. In a recent year, about 10,900 new cases were diagnosed (Torre et al., 2012). The increased risk of prostate cancer is positively correlated with a high intake of proteins contained in dairy products $(35 \mathrm{~g} /$ day $)$ and calcium from dairy products (Gonzalez and Riboli 2010, Allen et al. 2008). A food product that reduces the risk of prostate cancer is fish. It is recommended to consume it more often than three times a week (Khan et al., 2010). Likely food products containing lycopene, belonging to the carotenoids, show a protective effect against prostate cancer. Food sources of lycopene are tomatoes, papaya, watermelons, pink grapefruits, peaches, wild rose and their preparations (pastes, purees, concentrates, juices) (Wawrzyniak et al, 2005).

Breast cancer is the most common malignant cancer in women in Poland. It is also the second highest, after lung cancer, as the cause of deaths attributed to malignant tumors among women. As reported by the National Cancer Registry, the number of cases exceeds 16,500 cases per year (Jassem and Krzakowski, 2014). The immediate cause of breast cancer is not known; however, a group of independent risk factors has been identified. These include age $(80 \%$ of breast cancers occur after 50 years of age), geographical location (high-risk groups inhabit highly developed countries), increased exposure to endogenous and exogenous estrogens (early menses before 11 years of age, menopause after age 54, childlessness), first birth after the age of 40), and genetic factors (Dumitrescu and Cotarla 2005, Hulka and Moorman 2001). Research shows that the consumption of excessive amounts of red meat (pork, beef and mutton) as well as of processed meat is associated with an increased risk of breast cancer, especially in postmenopausal women (Taylor et al. 2007, Eunyoung et al. 2006, Ferrucci et al. 2009). According to Gonzalez and Riboli (2010), there is a positive correlation between the incidence of breast cancer and a high content of saturated fat in the diet. Reducing the fat content by following a lowenergetic diet serves to reduce the level of estrogens in the blood serum, the too high concentration of which may contribute to the development of breast cancer (Yager and Davidson, 2006). In addition, Gonzalez and Riboli (2010) are of the opinion that there are no reports that fruits and vegetables would reduce the risk of breast cancer. The observation carried out by Kruk (2006) contradicts this thesis. According to the author, the frequent eating of fruits and vegetables can reduce the risk of breast cancer. Of particular importance in cancer chemoprevention are cruciferous vegetables (white cabbage, red cabbage, Chinese broccoli, Italian cauliflower, broccoli, Brussels sprouts, radishes, rapeseed) (Beliveau and Gingras, 2011).

\section{CONCLUSIONS}

Nowadays, neoplastic diseases are the most common diseases of civilization, affecting both women and men regardless of their age. The incidence of cancer in the world and in Poland is constantly growing. In Poland, neoplastic diseases currently account for approximately $20 \%$ of all deaths, including about $40 \%$ of deaths in women aged 45 to 65 and 30\% of deaths in men in the same age range. The growth rate of the number of malignant tumors in Poland is much higher than the growth rate of the population and is among the highest in Europe (Didkowska et al, 2017). The increase in the number of these diseases and the deaths caused by them in Poland can be attributed to five main causes: population growth, changes in the age structure of the population consisting in an increase in the number of age groups with particularly high incidence, insufficiently fast changes in pro-health attitudes (e.g. with regard to smoking and alcohol consumption), poor quality of nutrition, and slow, and unsatisfactory improvement in the early diagnosis of cancer. Whereas the average cancer cure rate in Poland for both sexes is $30 \%$, and in the Scandinavian and some West European countries it is $40 \%$, in the USA it is $50 \%$ (http://www.puo.pl/program-walkiz-rakiem/narodowy-program-zwalczania-chorobnowotworowych/epidemiologia). 
Most of the tumors are the result of the effects of lifestyle and the state of thenatural environment. Lifestyle means, among other things, but most importantly in this context, physical activity and a properly balanced diet. It is estimated that approximately 20 to $30 \%$ of all malignant tumors are diet-dependent cancers, in the development of which nutritional factors are significant (Kushi et al., 2006). Overeating is an extremely dangerous phenomenon that generates the risk of obesity, which is the main factor causing an increase in the incidence of malignant tumors. The number of obese people is increasing in Poland, especially in the 35 to 64 age group. Overweight and obesity are associated with an increased risk of developing many cancers, such as breast cancer in postmenopausal women, colon cancer, endometrial cancer, adenoma and esophageal cancer. Excessive supply of energy components and low physical activity cause an increase in body fat, which significantly affects the metabolism of estrogen in women, which may stimulate the development of breast cancer (Pudlo et al. 2015) Too much processed, high-calorie food, saturated with preservatives, first of all burdens the body's systems, particularly the digestive, circulatory and respiratory, and then leads to oncological disorders. It is reasonable to conclude that diet plays a major role in the development of more than a third of all cancer cases. There are several well-documented links between diet and the causes of cancer. One of the diets that reduce the risk of cancer is the Mediterranean diet. It is characterized by increased consumption of vegetables, fruits, oil, and fish and by limited consumption of red meat. The diet contains the majority of anti-inflammatory and antioxidant nutrients (phytochemicals and omega-3 acids), which reduce the risk of cancer. The Mediterranean diet is particularly beneficial for reducing the incidence of prostate cancer and colorectal cancer (Pudlo et al., 2015).

Forecasts for the coming years, which show an increased incidence of cancer in Poland, demonstrate the need for an increased awareness of the role of diet in the prevention of morbidity. Among the types of cancer most commonly afflicting Poles are lung cancer, associated mainly with smoking, and colorectal cancer. Colon cancer is one of the cancers most highly affected by genetic factors, but its incidence is increased by inappropriate lifestyle choices, in particular a poor diet, especially when it contains very little fiber. Extremely important in the context of cancer prevention is awareness of the type of food consumed, its source, its processing, and its energy value. Research shows that people with a higher level of knowledge about the prevention of cancer are taking lifestyle decisions that are more beneficial to their health.
Lack of awareness regarding dietary cancer prevention is likely to be a major factor in the steady increase that has been predicted in the incidence of these diseases. Running programs of nutritional education especially for children and adolescents may help to reduce the incidence of food-dependent cancers in Poland.

\section{REFERENCES}

1. Allen N.E., Key T.J., Appleby P.N., Travis R.C., Roddam A.W., Tjonneland A., et al.: Animal foods, protein, calcium and prostate cancer risk: the European Prospective Investigation into Cancer and Nutrition. Br. J. Cancer, 2008;98(9):1574-1581.

2. Ames B.N.: Low micronutrient intake may accelerate the degenerative diseases of aging through allocation of scarce micronutrients by triage. Proc. Natl. Acad. Sci. USA, 2006; 103:17589-17594.

3. Andreasen M.F., Kroon P.A., Williamson G., GarciaConesa $M-T$.: Intestinal release and uptake of phenolic antioxidant diferulic acids. Free Rad. Biol. Med., 2001;31(3):304-314.

4. Augenlicht L.: Colon cancer prevention: Dietary modulation of cellular and molecular mechanisms. Nutrition, 1999;15:648-650.

5. Barone M., Tanzi S., Lofano K., Scavo M.P., Guido R., Demarinis L., Principi M.B., Bucci A., Di Leo A.: Estrogens, phytoestrogens and colorectal neoproliferative lesions. Genes Nutr., 2008;3:7-13.

6. Bast A., Haenen G.R.M.M.: The toxicity of antioxidants and their metabolites. Environ. Toxicol. Pharmacol., 2002;11:251-258.

7. Beliveau R., Gingras D.: Dieta w walce $\mathrm{z}$ chorobami. Delta, Warszawa 2011. (in Polish).

8. Bermudez-Soto M.J., Larrosa M., Garcia-Cantalejo J.M., Espin J.C., Tomas-Barberan F.A., Garcia-Conesa M.T.: Up-regulation of tumor suppressor carcinoembryonic antigen-related cell adhesion molecule 1 in human colon cancer Caco-2 cells following repetitive exposure to dietary levels of a polyphenol-rich chokeberry juice. J. Nutr. Biochem., 2007; 18:259-271.

9. Bingham S.A.: Mechanisms and experimental and epidemiological evidence relating dietary fiber (nonstarch polysaccharides) and starch to protection against large bowel cancer. P. Nutr. Soc. 1990;49:153-171.

10. Chung F.L., Conaway C.C., Rao C.V., Reddy B.S.: Chemoprevention of colonic aberrant crypt foci in Fischer rats by sulforaphane and phenethyl isothiocyanate. Carcinogenesis, 2000;21:2287-2291.

11. Ciborowska H., Rudnicka A.: Dietetyka. Zywienie zdrowego i chorego czlowieka. Wydawnictwo Lekarskie PZWL, Warszawa 2012, 478-483. (in Polish).

12. D'Elia L., Galletti F., Strazzullo P.: Dietary salt intake and risk of gastric cancer. Cancer Treat Res., 2014;159:83-95.

13. DeVita V.T. Jr.M.D., Lawrence T.S., Rosenberg S.A.: Cancer: Principles \& Practice of Oncology. Primer of the Molecular Biology of Cancer. Wolters Kluwer. Philadelphia 2015. 
14. DidkowskaJ., Wojciechowska U., Zatoński W.:Prognozy zachorowalności i śmiertelności na nowotwory złośliwe w Polsce do 2025 roku, Krajowy Rejestr Nowotworów, Centrum Onkologii - Instytut im. Marii Skłodowskiej Curie. Warszawa, 2009). (in Polish).

15. Didkowska J., Wojciechowska U., Olasek P.: Nowotwory złośliwe w Polsce w 2015 roku. Krajowy Rejestr Nowotworów, Centrum Onkologii - Instytut im. Marii Sklodowskiej - Curie. Warszawa, 2017. (in Polish).

16. Dumitrescu R.G., Cotarla I.: Understanding breast cancer risk - where do we stand in 2005? J Cell. Mol. Med, 2005;9:208-221.

17. Eunyoung Ch., Chen W.Y., Hunter D.J.: Red Meat Intake and Risk of Breast Cancer Among Premenopausal Women. Arch. Intern. Med., 2006;166:2253-2259.

18. Europejski Raport Zdrowia: Europejski Raport Zdrowia. Droga do osilagniecia dobrostanu. Swiatowa Organizacja Zdrowia 2013,6-7. (in Polish).

19. Fenech M., Baghurst P., Luderer W., Turner J., Record S., Ceppi M., Bonass S.: Low intake of calcium, folate, nicotinic acid, vitamin $\mathrm{E}$, retinol, beta-carotene and high intake of pantothenic acid, biotin and riboflavin are significantly associated with increased genome instability - results from a dietary intake and micronucleus index survey in South Australia. Carcinogenesis, 2005;26:991-999.

20. Feng R., Ni H.M., Wang S.Y., Tourkova I.L., Shurin M.R., Harada H., Yin X.M.: Cyanidin-3-rutinoside, a natural polyphenol antioxidant, selectively kills leukemic cells by induction of oxidative stress. J. Biol. Chem., 2007;282:13468-13476.

21. Ferlay J., Soerjomataram I., Dikshit R., Eser S., Mathers C., Rebelo M., Parkin D.M., Forman D., Bray F.: Cancer incidence and mortality worldwide: Sources, methods and major patterns in GLOBOCAN 2012. 2014;136(5):989-124.

22. Ferrucci L.M., Cross A.J., Graubard B.I., Brinton L.A., McCarty C.A. $i$ wsp.: Intake of meat, meat mutagens, and iron and the risk of breast cancer in the Prostate, Lung, Colorectal, and Ovarian Cancer Screening Trial. Brit. J. Cancer, 2009;101:178-184.

23. Fotiadis C.I., Stoidis C.N., Spyropoulos B.G., Zografos E.D.: Role of probiotics, prebiotics and synbiotics in chemoprevention for colorectal cancer. World $\mathrm{J}$. Gastroenterol., 2008;14:6453-6457.

24. Goncalves P., Marteal F. Butyrate and colorectal cancer: the role of butyrate transport. Curr. Drug Metab. 2013;14:994-1008.

25. Gonzalez C.A., Riboli E., Diet and cancer prevention: Contributions from the European Prospective Investigation into Cancer and Nutrition (EPIC) study, Eur. J. Cancer, 2010; 46(14):2555-2562.

26. Hakama M.: Chemoprevention of cancer. Acta Oncol, 1998;37:227-230.

27. Hamra G.B., Laden F., Cohen A.J., Raaschou-Nielsen O., Brauer M., Loomis D.: Lung Cancer and Exposure to Nitrogen Dioxide and Traffic: A Systematic Review and Meta-Analysis. Environ Health Perspect, 2015;123(11):1107-12.

28. Hawk E.T., Limburg P.J., Viner J.L.: Epidemiology and prevention of colorectal cancer. Surg. Clin. North. Am. 2002;82:905-941.
29. Hawrysz I., Krisińska B., Słowińska M. A., Wadołowska L., Czerwińska A., Biernacki M.: Jakość diety a ryzyko raka piersi lub płuc: badania kliniczno-kontrolne osób dorosłych z regionu Warmii i Mazur. Pobl Hig Epidemiol. 2015; 96(4): 753-756.

30. Hosseini M., Naghan P. A., Jafari A.M., Yousefifard M., Taslimi S., Khodadad K., Mohammadi F., Sadr M., Rezaei M., Mortaz E., Masjedi M. R.: Nutrition and lung cancer: a case control study in Iran. BMC Cancer, 2014;14:860.

31. Hulka B.S., Moorman P.G.: Breast cancer: hormones and other risk factors. Maturitas, 2001;38:103-116.

32. Jacobs E.T., Haussler M.R., Martinez M.E.: Vitamin D activity and colorectal neoplasia: a pathway approach to epidemiologic studies. Cancer Epidemiol. Biomarkers Prev., 2005; 14:2061-2063.

33. Jarosz M.: Co uratowalo setki tysiecy osob w Polsce przed zachorowaniem na raka w latach 1990 - 2013. II Narodowy Kongres Zywieniowy. Zywnosc, Zywienie w prewencji i leczeniu - postepy 2016. Instytut Zywnosci i Zywienia im. Prof. dra med. Aleksandra Szczygla, Warszawa 2017,9-10. (in Polish).

34. Jarosz M., Sajor I.: Prewencja w nowotworach zlosliwych [w:] Jarosz M. red.: Praktyczny Podrecznik Dietetyki. Wydawnictwo Instytutu Zywnosci i Zywienia, Warszawa 2010,399-413. (in Polish).

35. Jarosz M., Sajor I.: Zywienie a choroba nowotworowa. Poradnik dla pacjentow i ich rodzin. PRIMOPRO, Warszawa 2013. (in Polish).

36. Jassem J., Krzakowski M.: Rak piersi. Praktyczny przewodnik dla lekarzy. Wydawnictwo Via Medica, Gdansk 2014. (in Polish).

37. Kaledkiewicz E., Lange E.: Znaczenie wybranych związków pochodzenia roślinnego w diecie zapobiegajlacej chorobom nowotworowym. Postepy Fizjoterapii, 2013,1:42-47. (in Polish).

38. Kaput J., Rodriguez R.L.: Nutritional genomics: the next frontier in the postgenomic era. Physiol. Genomics, 2004;16:166-177.

39. Khan N., Afaq F., Mukhtar H., Lifestyle as risk factor for cancer: Evidence from human studies. Cancer Lett. 2010; 293(2):133-143.

40. Koutsokera, A., Kiagia, M., Saif, M.W., Souliotis, K., Syrigos, K.N.: Nutrition habits, physical activity, and lung cancer: an authoritative review. Clinical Lung Cancer. 2013;14(4): 342 - 350.

41. Kruk J.: Jedzenie owocow i warzyw a ryzyko raka piersi. Wspolczesna Onkologia, 2006; 10(5):224-230. (in Polish).

42. Kunnumakkara A.B., Guha S.M.D., Aggarwal B.B.: Curcumin and colorectal cancer: add spice to your life. Curr. Colorectal Cancer Rep., 2009;5:5-14.

43. Kushi L.H., Byers T., Doyle C., Bandera E.V., McCullough M., Gansler T., Andrews K.S., Thun M.J.: Wytyczne American Cancer Society dotyczące Żywienia i aktywności fizycznej w zapobieganiu nowotworom złośliwym: zmniejszanie ryzyka nowotworów przez wybór prawidłowych nawyków Żywieniowych i wysiłek fizyczny, CA Cancer J. Clin. 2006;56:254-281. (in Polish).

44. Mitek M., Anyżewska A., Wawrzyniak A. Estimated dietary intakes of nitrates in vegetarians compared to a traditional diet in Poland and acceptable daily intakes: is there a risk? Rocz. Panstw. Zakl. Hig, 2013;64(2):105-109 (in Polish).

45. Moorthy B., Chu C., Carlin D.J.: Polycyclic aromatic hydrocarbons: from metabolism to lung cancer. Toxicol Sci., 2015;145(1):5-15. 
46. Nguyen M.L., Schwatz S.J.: Lycopene: chemical and biological properties. Food Technol., 1999;53:38-45.

47. Park M.K., Li W.Q., Qureshi A.A., Cho E.: Fat Intake and Risk of Skin Cancer in U.S. Adults. Cancer Epidemiol Biomarkers Prev., 2018;27(7):776-782.

48. Peters U., McGlynn K.A., Chatterjee N., Gunter E., Garcia-Closas M., Rothman N., Sinha R.: Vitamin $\mathrm{D}$, calcium, and vitamin $\mathrm{D}$ receptor polymorphism in colorectal adenomas. Cancer Epidemiol. Biomarkers Prev., 2001;10:1267-1274.

49. Pieszka M., Pietras M.: Nowe kierunki w badaniach żywnościowych - nutrigenomika. Rocz. Nauk. Zoot., 2010;37(2):83-103. (in Polish).

50. Pilis W., Stec K., Zych M., Pilis A. Health benefits and risk associated with adopting a vegetarian diet. Rocz Panstw Zakl Hig 2014;65(1):9-14.

51. Platz E.A., Giovannucci E.: Vitamin D and calcium in colorectal and prostate cancers. [w:] Heber D., Blackburn G.L., Go V.L.W. (red.) Nutritional Oncology. Academic Press, San Diego, 1999;223-252.

52. Pouchieu C., Galan P., Ducros V., Latino-Martel P., Hercberg S., Touvier M.: Plasma carotenoids and retinol and overall and breast cancer risk: a nested case-control study. Nutr. Cancer, 2014;66(6):980-8.

53. Pudlo H., Respondek M., Szefczyk-Polowczyk L., Wengel-Wozny K.: The impact of diet on the occurrence of tumor diseases. Journal of Education, Health and Sport, 2015;5(9):549-558.

54. Raport, Rak pluca standardy diagnostyki i leczenia w Polsce, Fundacja Wygrajmy Zdrowie, Warszawa, 2015. (in Polish).

55. Report World Cancer Research Fund and American Institute for Cancer Research: World Cancer Research. Fund Global Network. Washington 2007.

56. Robles-Almazan M., Pulido-Moran M., MorenoFernandez J., Ramirez-Tortosa C., Rodriguez-Garcia C., Quiles J.L.: Ramirez-Tortosa M.: Hydroxytyrosol: Bioavailability, toxicity, and clinical applications. Food Res. Int., 2018;105:654-667.

57. Schatzkin A. Going against the grain? Current status of the dietary fiber-colorectal cancer hypothesis. Biofactor, 2000;12:305-311.

58. Singletary K.W., Jung K.J., Giusti M.: Anthocyanin-rich grape extract blocks breast cell DNA damage. J. Med. Food, 2007;10:244-251.

59. Sisto M., Lisi S., D'Amore M., De Lucro R., Carati D., Castellana D., La Pesa V., Zuccarello V., Lofrumento D.D.: Saponins from Tribulus terrestris L. protect human keratinocytes from UVB-induced damage. J. Photochem. Photobiol. B., 2012;117:193-201.

60. Song Y., Liu M., Yang F.G., Cui L.H., Lu X.Y., Chen $C .:$ Dietary fibre and the risk of colorectal cancer: a case-control study. Asian Pac. J. Cancer Prev., 2015;16(9):3747-3752.

61. Szlitkus P.: Epidemiology of lung cancer in Poland. Letters in Oncology Science 2018; 15(2):71-77.

62. Tantamango-Bartley Y., Jaceldo-Siegl K., Fan J., Fraser $G$.: Vegetarian diets and the incidence of cancer in a low-risk population. Cancer Epidemiol Biomarkers Prev., 2013; 22(2):286-294.
63. Taylor E.F., Burley V.J., Greenwood D.C., Cade J.E.: Meat consumption and risk of breast cancer in the UK Women's Cohort Study. Brit. J. Cancer, 2007;96:1139-1146.

64. Torre L.A., Bray F., Siegel R.L., Ferlay J., LortetTieulent J., JemelA.: Global cancer statistics, 2012. CA Cancer J. Clin., 2015;65(2):87-108.

65. Trepel F.: Dietary fibre: more than a matter of dietetics. I. Compounds, properties, physiological effects. Wien Klin. Wochenschr, 2004;116:465-476.

66. Turati F., Carioli G., Bravi F., Ferraroni M., Serraino D., Montella M., Giacosa A., Toffolutti F., Negri E., Levi F., La Vecchia C.: Mediterranean Diet and Breast Cancer Risk. Nutrients, 2018;10(3).

67. Twardak I. M., Konikowska K., Krainska A., Lisowska A., KrzyZanowski D.: Rola diety w rozwoju raka prostaty. Piel. Zdr. Publ. 2015;5(4):417-425. (in Polish).

68. Valko M., Rhodes C.J., Moncol J., Izakovic M., Mazur M.: Free radicals, metals and antioxidants in oxidative stress-induced cancer. Chem. Biol. Interact, 2006;160(1):1-40.

69. Varela-Rey M., Woodhoo A., Matrinez-Chantar M.L., Mato J. M., Lu S.C.: Alcohol, DNA Methylation, and Cancer. Alcohol Res., 2013;35(1):25-35.

70. Wakai K., Date C., Fukui M., Tamakoshi K., Watanabe Y., Hayakawa N., Kojima M., Kawado M., Zuzuki K., Hashimoto S., Tokudome S., Ozasa K., Suzuki S., Toyoshima H., Ito Y., Tamakoshi A., JACC Study Group. Dietary fiber and risk of colorectal cancer in the Japan collaborative cohort study. Cancer Epidemiol. Biomarkers Prev., 2007;16:668-675.

71. Wawrzyniak A., Marciniak A., Rajewska J.: Lycopene content of selected foods available on the polish market and estimation of its intake. Pol. J. Food Nutr. Sci. 2005;14,195-200.

72. Willett W.C.: Diet and cancer. Oncologist, 2000;5:393-404.

73. Xiao Q., Freedman N.D., Ren J., Hollenbeck A.R., Abnet C.C., Park Y.: Intakes of folate, methionine, vitamin $\mathrm{B}_{6}$, and vitamin $\mathrm{B}_{12}$ with risk of esophageal and gastric cancer in a large cohort study. Br. J. Cancer, 2014;110(5):1328-33.

74. Yager J.D., Davidson N.E.: Estrogen Carcinogenesis in Breast Cancer. N. Engl. J. Med., 2006;354:270-282.

75. Yen H., Li W.Q., Dhana A., Li T., Qureshi A., Cho $E$.: Red meat and processed meat intake and risk for cutaneous melanoma in white women and men: Two prospective cohort studies. J. Am. Acad. Dermatol., 2018;79(2):252-257.

76. Zhang Y., Vareed S.K., Nair M.G.: Human tumor cell growth inhibition by nontoxic anthocyanidins, the pigments in fruits and vegetables. Life Sci., 2005;76:1465-1472.

77. Zyski R., Wysocki P., Wyrwicz L.: Rak jelita grubego społeczne znaczenie zmian w zakresie epidemiologii i możliwości leczenia w Polsce. Onkologia w Praktyce Klinicznej 2014;10 (4):212-223. (in Polish).

78. http://www.puo.pl/program-walki-z-rakiem/narodowyprogram-zwalczania-chorob-nowotworowych/ epidemiologia (Accessed 8.03.2019). (in Polish).

Received: 03.08.2019

Accepted: 25.10 .2019 